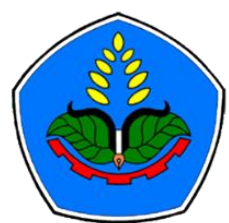

AGROPROSS

National Conference

Proceedings of Agriculture

\section{Proceedings:}

Peningkatan Produktivitas Pertanian Era Society 5.0 Pasca Pandemi

Tempat : Politeknik Negeri Jember

Tanggal : 22 Juli 2021

Publisher :

Agropross, National Conference Proceedings of Agriculture

ISBN : 978-623-94036-6-9

DOI : 10.25047 /agropross.2021.223

\title{
Penanganan Pasca Panen Sayuran Serta Strategi Sosialisasinya Kepada Masyarakat Ditengah Pandemi Covid-19
}

\author{
Author(s): Nor Isnaeni Dwi Arista ${ }^{(1)}$ \\ (1) Universitas Sebelas Maret \\ * Corresponding author: dewi.arista99@student.uns.ac.id
}

\section{ABSTRACT}

The COVID-19 pandemic has a tremendous impact on health. To maintain health, people always pay attention to lifestyle, including consumption. Increasing of vegetable consumption is directly proportional to the demands of public health during the pandemic. However, knowledge about how to store vegetables in the community is not yet fully distributed. One of the proper post-harvest handling of vegetables by utilizing technology is using a refrigerator. The study used types of spinach (leaf vegetables) and eggplant (fruit vegetables). The research aims to get the best treatment in storing leaf vegetables and fruit vegetables and to determine the post-harvest handling socialization strategy for the community. The research was conducted in Jebres, Surakarta. The study used a Factorial Completely Randomized Design with 2 factors, there were storage temperature (room temperature and low) and PP plastic packaging (packaged and unpackaged), and 7 replications. The research data were analyzed using descriptive methods with observation techniques and literature studies. The results showed that both leaf vegetables and fruit vegetables had a longer shelf life at low-temperature storage using packaging. Then a proper post-harvest handling socialization strategy is needed to increase public knowledge to maintain the shelf life of vegetables amid the COVID-19 pandemic.

\section{Kata Kunci: ABSTRAK}

pascapanen,

bayam,

terung.

Pandemi COVID-19 memberikan dampak luar biasa utamanya aspek kesehatan. Dalam rangka menjaga kesehatan, masyarakat selalu memperhatikan gaya hidup termasuk pada konsumsi. Peningkatan konsumsi sayuran berbanding lurus dengan tuntutan kesehatan masyarakat di masa pandemi. Namun, pengetahuan mengenai cara penyimpanan sayuran

\section{Keywords:}

spinach,

eggplant,

postharvest,

covid-19

pandemic. di masyarakat belum sepenuhnya merata. Salah satu penanganan pasca panen sayuran yang tepat dengan memanfaatkan teknologi yakni menggunakan lemari pendingin. Penelitian menggunakan jenis sayur bayam cabut (sayur daun) dan terung (sayur buah). Penelitian bertujuan untuk mendapatkan perlakuan terbaik dalam menyimpan sayuran daun dan sayuran buah serta menentukan strategi sosialisasi penanganan pasca panen kepada masyarakat. Penelitian dilaksanakan di Jebres, Surakarta. Penelitian menggunakan Rancangan Acak Lengkap (RAL) faktorial dengan 2 faktor yakni suhu penyimpanan (suhu ruang dan rendah) serta kemasan plastik PP (kemasan dan tanpa kemasan) dan 7 kali ulangan. Data hasil penelitian dianalisis dengan menggunakan metode deskriptif dengan teknik observasi dan studi literatur. Hasil penelitian menunjukkan bahwa baik sayur daun dan sayur buah memiliki umur simpan lebih lama pada penyimpanan di suhu rendah menggunakan kemasan. Kemudian diperlukan strategi sosialisasi penanganan pasca panen yang tepat agar meningkatkan pengetahuan masyarakat untuk mempertahankan umur simpan sayuran ditengah pandemic COVID19. 


\section{PENDAHULUAN}

Sayuran adalah sumber vitamin tinggi yang kaya manfaat. Permintaan sayuran cenderung meningkat, terlebih pada masa pandemi COVID-19 masyarakat selalu memperhatikan pola konsumsinya untuk menambah daya tahan tubuh agar terhindar dari virus corona. Masyarakat Indonesia mengonsumsi sayuran $(97,29 \%)$ dengan rata-rata konsumsi perorang perminggu sebanyak 0,092 kg (BPS, 2017). Bagian tanaman yang dikonsumsi berupa daun atau buah. Sayuran daun berupa bayam, kangkung, sawi, pakchoy dan lainnya. Sayuran jenis buah seperti terung, cabai, wortel, paprika, dan lainnya. Berdasarkan warna buahnya, dikenal jenis terung hijau, terung putih dan terung ungu (Juhaeti dan Peni, 2016). Jenis sayur-sayuran baik sayur daun maupun buah tersebut mempunyai daya tahan yang berbeda-beda setelah panen (Yuarini et al., 2015). Sifat dari sayuran yakni mudah rusak, sehingga lebih diutamakan untuk tujuan konsumsi dalam kondisi segar. Kerusakan yang terjadi pada sayuran disebabkan karena bagian yang telah dipanen tersebut masih melakukan proses metabolisme dengan menggunakan cadangan makanan yang terdapat dalam sayuran tersebut. Faktor-faktor yang menyebabkan turunnya kualitas dan susut panen sayuran diantaranya adalah turunnya kadar air, kerusakan mekanis, penguapan, berkembangnya mikroba dan sensitivitas terhadap etilen (Herdiani, 2015). Kerusakan juga dapat terjadi secara alamiah setelah dipanen akibat aktivitas berbagai jenis enzim yang menyebabkan penurunan nilai ekonomi dan gizi. Kerusakan hortikultura dapat lebih cepat bila penanganan selama panen atau sesudah panen kurang baik. Oleh karena itu perlu dilakukan upaya untuk mempertahankkan kualitas produk dengan melakukan penangan pasca pananen pada sayuran.

Penanganan pasca panen sayuran memiliki tujuan untuk menjaga agar sayuran tetap baik mutunya dan segar, sayuran menjadi menarik, terjamin dan sayuran lebih awet. Penanganan pascapanen dimulai ketika sayuran dipanen sampai dengan siap dikonsumsi, salah satu proses penting yaitu penyimpanan. Penyimpanan produk sayuran segar dimaksudkan untuk memperpanjang daya gunanya dan dalam keadaan tertentu dapat memperbaiki mutu (Abriana dan Laga, 2019). Penyimpanan dapat dilakukan pada suhu rendah untuk memperpanjang umur simpan. Kegiatan pascapanen dimaksudkan untuk mempertahankan mutu produk segar agar tetap prima, sehingga menekan kehilangan karena penyusutan dan kerusakan, memperpanjang daya simpan dan meningkatkan nilai ekonomis hasil pertanian. Upaya penanganan pasca panen juga dapat dilakukan dengan pengemasan, sehingga akan memperlambat kebusukan pada sayur.

Berdasarkan pembahasan diatas, maka perlu adanya penelitian untuk mempertahankan umur simpan sayuran pasca panen jenis sayuran daun (bayam) dan buah (terung) serta strategi sosialisasinya pada masyarakat di masa pandemic COVID-19, hal ini dikarenakan masih terbatasnya referensi terkait penerapan sosialisasi tersebut.

\section{BAHAN DAN METODE}

Penelitian dilaksanakan pada bulan Januari 2021 di Jebres Surakarta, Jawa Tengah. Bahan yang digunakan yaitu plastik PP, sayur bayam dan terung. Alat yang digunakan yaitu lemari pendingin. Penelitian menggunakan Rancangan Acak Lengkap (RAL) faktorial yang terdiri dari 2 faktor perlakuan. Faktor pertama adalah suhu pernyimpanan dengan 2 taraf yakni suhu ruang dan rendah. Faktor kedua adalah perlakuan kemasan dengan 2 taraf yaitu tanpa kemasan dan dengan kemasan. Perlakuan tersebut dikombinasikan sehingga terdapat 4 kombinasi pada 
masing-masing komoditi sayur, serta pengulangan sebanyak 7 kali. Pengamatan dilakukan setiap hari dengan rentang waktu hingga 14 hari. Data hasil penelitian dianalisis dengan menggunakan metode deskriptif dengan teknik observasi dan studi literatur.

Berikut adalah masing-masing perlakuan pada penelitian B1P1: bayam tanpa kemasan plastik PP pada suhu ruang, B1P2: bayam tanpa kemasan plastik pada suhu rendah, B2P1: bayam dengan kemasan plastik pada suhu ruang, B2P2: bayam dengan kemasan plastik pada suhu rendah, T1P1: terung tanpa kemasan plastik pada suhu ruang, T1P2: terung tanpa kemasan plastik pada suhu rendah, T2P1: terung dengan kemasan plastik pada suhu ruang, T2P2: terung dengan kemasan plastik pada suhu rendah.

Penelitian diawali dengan membeli sayur bayam segar yang masih ada akarnya dan terung ungu yang ukurannya seragam, kemudian disortasi. Pengemasan dilakukan dengan cara memasukkan sayur bayam dan terung kedalam plastik PP dan tanpa kemasan. Selanjutnya diletakkan pada suhu ruang dan suhu rendah sesuai dengan perlakuan.

Variabel pengamatan penelitian terdiri dari tekstur, warna, dan umur simpan sayuran. Pengamatan tekstur pada bayam dan terung (tingkat kekerasan sayur) dengan scoring: $1=$ lunak sekali, $2=$ lunak, $3=$ agak lunak, $4=$ keras. Warna bayam dengan scoring: $1=$ hijau, $2=$ hijau kekuningan, $3=$ kuning, $4=$ kuning kecoklatan, $5=$ coklat. Sedangkan warna pada terung dengan scoring: $1=$ ungu, $2=$ ungu tua, $3=$ coklat muda, $4=$ coklat tua. Umur simpan diamati dengan menghitung hari lamanya sayuran bertahan dari awal penyimpanan sampai rusak apabila dalam 1 ikat telah rusak dan tersisa $25 \%$ bagian yang baik.

\section{HASIL DAN PEMBAHASAN Umur Simpan}

Berdasarkan gambar 1. menunjukkan bahwa bayam pada perlakuan tanpa kemasan di suhu ruang tanpa dan dengan kemasan berturut-turut memiliki umur simpan paling lama 6 dan 7 hari. Berdasarkan tabel 1. bayam yang tidak layak konsumsi bertekstur lunak sekali dan berwarna coklat dengan sedikit aroma menyengat yang menandakan terjadi pembusukan. Pembeda dari hasil akhir penanganan pascapanen dengan dan tanpa kemasan plastik pada bayam yaitu pada kemasan di suhu ruang memiliki lebih banyak lendir, lunak sekali, dan berair, sedangkan bayam tanpa kemasan di suhu ruang memiliki tekstur lunak dan berlendir. Bayam dengan perlakuan dengan kemasan di suhu rendah menjadi perlakuan terbaik karena selama umur simpan 11 hari bayam belum rusak sepenuhnya. Perlakuan bayam tanpa kemasan di suhu rendah memiliki umur simpan 7 hari dengan hasil akhir bertekstur agak lunak, berwarna kuning kecoklatan dan cenderung kering namun tidak berbau. Akan tetapi berbeda pada bayam yang dibungkus plastik dan ditempatkan di suhu ruang maka akan cepat busuk. Berdasarkan penelitian yang dilakukan oleh Hakiki (2016) bahwa perubahan kualitas bayam berupa warna, klorofil, kandungan nitrat, total padatan terlarut, asam askorbat, dan total antioksi dan diamati selama penyimpanan. Bayam yang segar masih terjaga warna hijaunya, namun seiring dengan penyimpanan, bayam mulai menurun kualitasnya ditandai dengan warna bayam mulai menguning. Bayam (Spinacia oleraceae L.) merupakan sayuran dengan tingkat respirasi yang tinggi mencapai $40-70 \mathrm{~mL} \quad \mathrm{CO}_{2} / \mathrm{kg}-\mathrm{h}$ sehingga rentan dengan penurunan kualitas. Seperti jenis sayuran yang lain, bayam mudah layu dan busuk. Oleh karena itu, bayam yang habis dipanen harus segera dipasarkan dan dikonsumsi. Pada suhu kamar, kesegaran daun bayam hanya dapat bertahan selama 12 jam, untuk mempertahankan kesegaran bayam selama 
belum dikonsumsi, dapat dilakukan penyimpanan. Bayam dapat disimpan dengan cara mencelupkan bagian akar sayuran dalam air atau disimpan dalam lemari pendingin. Penyimpanan dalam lemari pendingin dapat memperpanjang kesegaran bayam sampai $12-14$ hari. Kondisi simpan yang baik adalah pada suhu antara $12,8-21,10^{\circ} \mathrm{C}$ (Yudhistira et al., 2019).

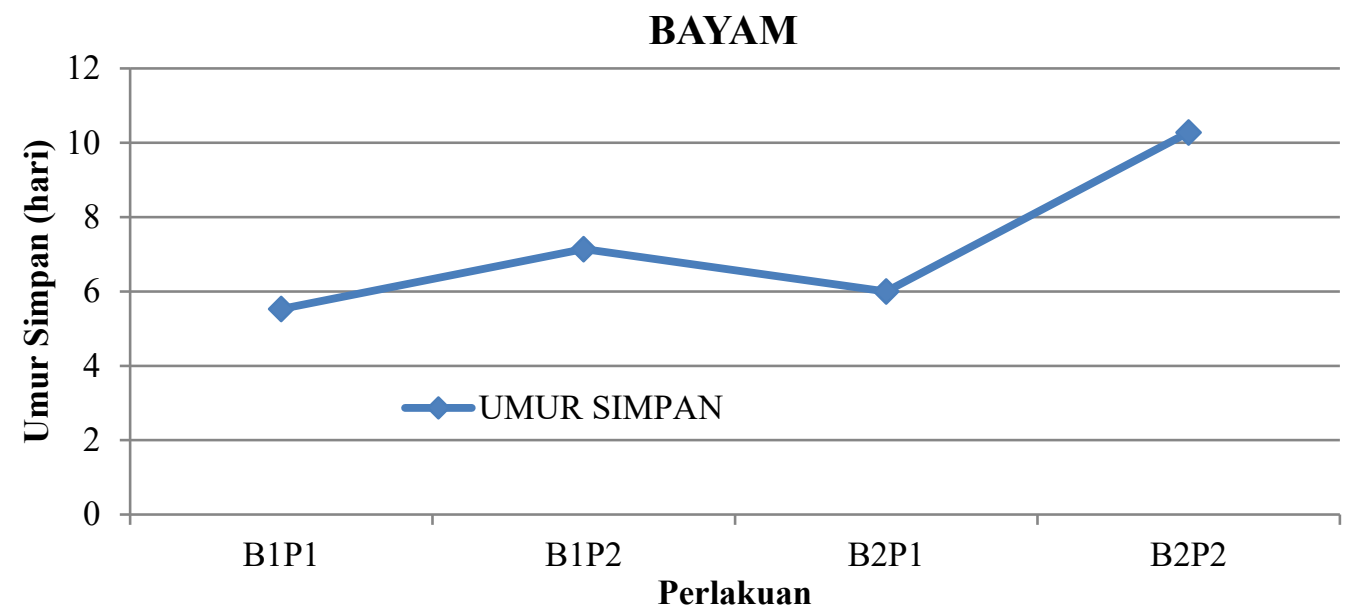

Keterangan:

Gambar 1. Grafik umur simpan bayam

B1P1: bayam tanpa kemasan plastik pada suhu ruang,

B1P2: bayam tanpa kemasan plastik pada suhu rendah, B2P1: bayam dengan kemasan plastik pada suhu ruang, B2P2: bayam dengan kemasan plastik pada suhu rendah

TERUNG

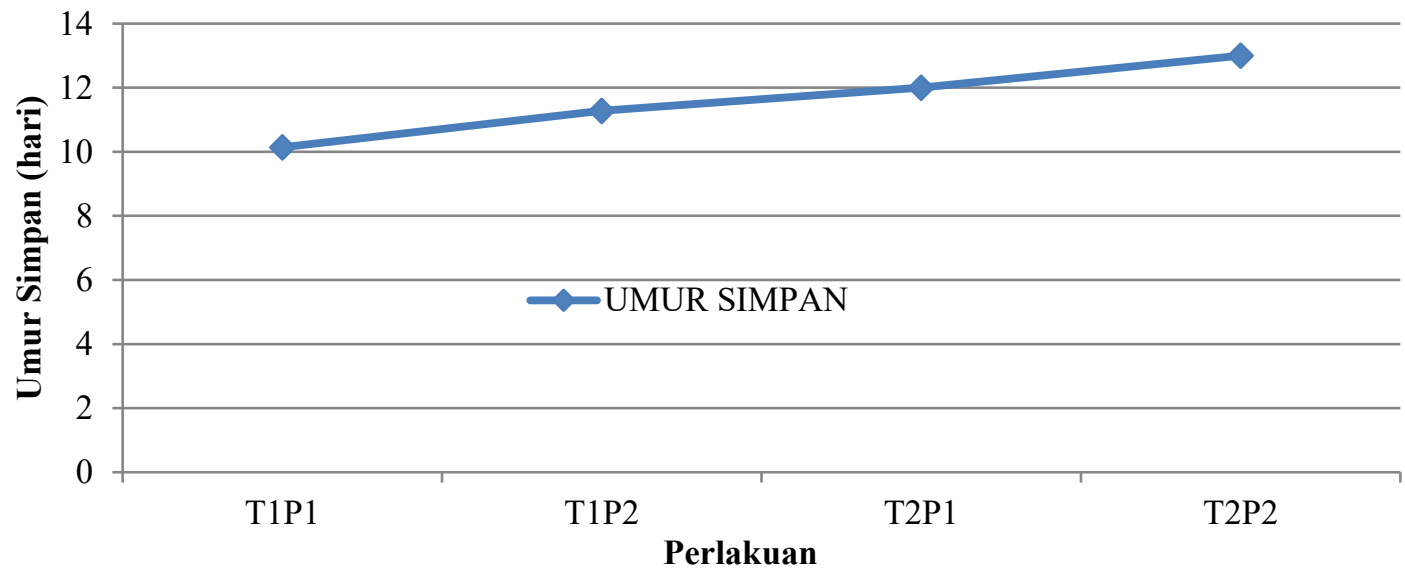

Keterangan:

Gambar. 2 Grafik umur simpan terung

T1P1: terung tanpa kemasan plastik pada suhu ruang,

T1P2: terung tanpa kemasan plastik pada suhu rendah,

T2P1: terung dengan kemasan plastik pada suhu ruang,

T2P2: terung dengan kemasan plastik pada suhu rendah

Berdasarkan gambar 2. perlakuan pada

menjadi perlakuan terbaik karena selama komoditas terung yang disimpan dengan umur simpan $>14$ hari terung masih kemasan ditempatkan di suhu rendah bertekstur keras dan berwarna ungu. 
Berdasarkan tabel 2. hal ini berbanding terbalik dengan penyimpanan terung di suhu ruang dengan kemasan mengalami pembusukan yang lebih cepat daripada perlakuan lain. Terung dengan perlakuan tanpa kemasan di suhu ruang memiliki hasil akhir tekstur yang agak lunak dan warna mendekati coklat atau hampir busuk. Terung tanpa kemasan di suhu rendah memiliki hasil akhir yaitu bertekstur lunak dan berwarna ungu tua. Hal ini disebabkan karena adanya respirasi yang terjadi. Diperkuat dengan penelitian Roiyana et al. (2012) meningkatnya laju respirasi akan menyebabkan perombakan senyawa seperti karbohidrat dalam buah dan menghasilkan $\mathrm{CO} 2$, energi dan air yang menguap melalui permukaan kulit buah yang menyebabkan kehilangan bobot pada buah. Penggunaan kantong yang tertutup rapat menghadapi masalah utama, yaitu udara yang terdapat di dalamnya tergantung pada suhu; permeabelitas plastik terhadap gas tidak tergantung pada suhu sedangkan bahan segar respirasinya dipengaruhi oleh suhu. Apabila suhu didalam kantong plastik yang tertutup rapat bervariasi beberapa derajat akan terjadi resiko besar, kecuali komoditi di dalam kantong tersebut laju respirasinya rendah atau toleran terhadap konsentrasi karbon dioksida dan oksigen yang bervariasi besar.

Pengamatan perubahan warna pada buah terung dilakukan secara organoleptik yang didasarkan pada proses pengindraan, yaitu indra penglihatan. Hasil pengamatan pada tabel 2. terhadap warna tersebut menunjukkan bahwa buah terung ungu rata-rata masih dapat mempertahankan warnanya sampai dengan penyimpanan. Proses pemasakan buah disertai dengan perubahan kandungan pektin oleh aktivitas enzim yang menyebabkan buah menjadi lunak. Pelunakan pada buah berhubungan secara langsung dengan kehilangan air dari buah. Peningkatan pelunakan disebabkan oleh terjadinya penguapan air. Air dari sel yang menguap menyebabkan sel menjadi mengecil, ruang antar sel menjadi menyatu dan zat pektin yang berada pada ruang antar sel akan saling berkaitan.

Sayuran pascapanen memiliki fungsi metabolisme masih berlanjut. Namun tidak sama dengan tanaman induk yang tumbuh pada lingkungan aslinya. Laju respirasi mengindikasikan laju metabolisme secara keseluruhan tanaman sehingga mempengaruhi mutu sayuran. Untuk menghambat laju respirasi yaitu dengan penyimpanan suhu rendah. Berdasarkan penelitian Asgar (2017) bahwa prinsip penyimpanan pada suhu rendah atau pendinginan menyatakan bahwa pada setiap penurunan suhu $8^{\circ} \mathrm{C}$, kecepatan reaksi metabolisme berkurang setengahnya. Usaha mempertahankan mutu dan memperpanjang umur simpan pada dasarnya adalah menekan laju respirasi serendah mungkin tanpa mengganggu proses metabolismenya.

Usaha menekan respirasi dalma penelitian menggunakan perlakuan kemasan plastik PP dan tanpa kemasan. Berdasarkan penelitian yang dilakukan Waryat dan Handayani (2020), pemakaian kemasan plastik dan penyimpanan pada suhu rendah, menjadi solusi yang dapat dipilih untuk mempertahankan mutu produk. Tujuan penyimpanan suhu rendah adalah untuk memperpanjang masa kesegaran sayuran guna menjaga keberlanjutan pasokan, menstabilkan harga dan mempertahankan mutu. Kemasan plastik dapat menyebabkan adanya perubahan kondisi udara lingkungan atau modifikasi atmosfer. Konsentrasi $\mathrm{CO}_{2}$ akan meningkat dan $\mathrm{O}_{2}$ menurun akibat interaksi dari respirasi komoditi yang dikemas dan permeabilitas bahan kemasan terhadap kedua gas tersebut. 
Tabel 1. Penanganan Pasca Panen Sayuran Bayam Hijau (Amaranthus gangeticus) Perlakuan Suhu Ruang dan Suhu Rendah

\begin{tabular}{|c|c|c|c|c|c|c|c|c|c|c|c|c|c|c|c|c|c|c|c|c|c|c|c|c|c|c|c|c|c|c|}
\hline \multirow{3}{*}{ Bahan } & \multirow{3}{*}{ UL } & \multirow{3}{*}{ US } & \multicolumn{28}{|c|}{ Hari ke- } \\
\hline & & & \multicolumn{2}{|c|}{1} & \multirow{2}{*}{\multicolumn{2}{|c|}{2}} & \multicolumn{2}{|c|}{3} & \multicolumn{2}{|c|}{4} & \multicolumn{2}{|c|}{5} & \multicolumn{2}{|c|}{6} & \multicolumn{2}{|c|}{7} & \multicolumn{2}{|c|}{8} & \multicolumn{2}{|c|}{9} & \multicolumn{2}{|c|}{10} & \multicolumn{2}{|c|}{11} & \multicolumn{2}{|c|}{12} & \multicolumn{2}{|c|}{13} & \multicolumn{2}{|c|}{14} \\
\hline & & & $\mathrm{T}$ & $\mathrm{W}$ & $\mathrm{T}$ & & $\mathrm{T}$ & $\mathrm{W}$ & $\mathrm{T}$ & $\mathrm{W}$ & $\mathrm{T}$ & $\mathrm{W}$ & $\mathrm{T}$ & $\mathrm{W}$ & $\mathrm{T}$ & $\mathrm{W}$ & $\mathrm{T}$ & W & $\mathrm{T}$ & $\mathrm{W}$ & $\mathrm{T}$ & W & $\mathrm{T}$ & W & $\mathrm{T}$ & $\mathrm{W}$ & $\mathrm{T}$ & $\mathrm{W}$ & $T$ & W \\
\hline & 1 & 5 & 4 & 1 & 2 & 2 & 2 & 4 & 1 & 4 & 1 & 4 & - & - & - & - & - & - & - & - & - & - & - & - & - & - & - & - & - & - \\
\hline & 2 & 6 & 4 & 1 & 3 & 2 & 2 & 3 & 2 & 4 & 1 & 5 & 1 & 5 & - & - & - & - & - & - & - & - & - & - & - & - & - & - & - & - \\
\hline & 3 & 4 & 4 & 1 & 4 & 2 & 3 & 4 & 2 & 5 & - & - & - & - & - & - & - & - & - & - & - & - & - & - & - & - & - & - & - & - \\
\hline B1P1 & 4 & 5 & 4 & 1 & 4 & 1 & 4 & 2 & 3 & 3 & 3 & 4 & - & - & - & - & - & - & - & - & - & - & - & - & - & - & - & - & - & - \\
\hline & 5 & 6 & 4 & 1 & 3 & 2 & 3 & 3 & 2 & 4 & 2 & 4 & 1 & 5 & - & - & - & - & - & - & - & - & - & - & - & - & - & - & - & - \\
\hline & 6 & 5 & 4 & 1 & 2 & 4 & 2 & 5 & 2 & 5 & 1 & 5 & - & - & - & - & - & - & - & - & - & - & - & - & - & - & - & - & - & - \\
\hline & 7 & 6 & 4 & 1 & 4 & 2 & 3 & 3 & 3 & 4 & 2 & 4 & 1 & 4 & - & - & - & - & - & - & - & - & - & - & - & - & - & - & - & - \\
\hline & 1 & 7 & 4 & 1 & 2 & 2 & 2 & 2 & 2 & 2 & 2 & 4 & 2 & 4 & 2 & 4 & - & - & - & - & - & - & - & - & - & - & - & - & - & - \\
\hline & 2 & 7 & 4 & 1 & 3 & 2 & 3 & 2 & 2 & 3 & 2 & 4 & 1 & 4 & 1 & 5 & - & - & - & - & - & - & - & - & - & - & - & - & - & - \\
\hline & 3 & 6 & 4 & 1 & 4 & 1 & 3 & 4 & 3 & 4 & 3 & 4 & 2 & 5 & - & - & - & - & - & - & - & - & - & - & - & - & - & - & - & - \\
\hline $\mathrm{B} 1 \mathrm{P} 2$ & 4 & 7 & 4 & 1 & 4 & 1 & 3 & 2 & 3 & 2 & 3 & 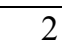 & 3 & 4 & 2 & 4 & - & - & - & - & - & - & - & - & - & - & - & - & - & - \\
\hline & 5 & 6 & 4 & 1 & 3 & 1 & 3 & 2 & 3 & 2 & 3 & 3 & 2 & 4 & 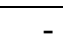 & - & - & - & - & - & - & - & - & - & - & - & - & - & - & - \\
\hline & 6 & 7 & 4 & 1 & 3 & 2 & 2 & 2 & 2 & 3 & 2 & 4 & 1 & 4 & 1 & 5 & - & - & - & - & - & - & - & - & - & - & - & - & - & - \\
\hline & 7 & 6 & 4 & 1 & 4 & 1 & 4 & 1 & 4 & 2 & 3 & 2 & 3 & 4 & - & - & - & - & - & - & - & - & - & - & - & - & - & - & - & - \\
\hline & 1 & 4 & 4 & 1 & 2 & 2 & 1 & 2 & 1 & 2 & - & - & - & - & - & - & - & - & - & - & - & - & - & - & - & - & - & - & - & - \\
\hline & 2 & 7 & 4 & 1 & 3 & 1 & 2 & 3 & 2 & 3 & 1 & 4 & 1 & 4 & 1 & 5 & - & - & - & - & - & - & - & - & - & - & - & - & - & - \\
\hline & 3 & 5 & 4 & 1 & 4 & 1 & 3 & 1 & 2 & 2 & 1 & 2 & - & - & - & - & - & - & - & - & - & - & - & - & - & - & - & - & - & - \\
\hline $\mathrm{B} 2 \mathrm{P} 1$ & 4 & 6 & 4 & 1 & 3 & 2 & 2 & 2 & 2 & 3 & 1 & 4 & 1 & 5 & - & - & - & - & - & - & - & - & - & - & - & - & - & - & - & - \\
\hline & 5 & 7 & 4 & 1 & 4 & 2 & 4 & 2 & 3 & 2 & 3 & 4 & 2 & 5 & 1 & 5 & - & - & - & - & - & - & - & - & - & - & - & - & - & - \\
\hline & 6 & 6 & 4 & 1 & 2 & 3 & 1 & 4 & 1 & 4 & 1 & 4 & 1 & 5 & - & - & - & - & - & - & - & - & - & - & - & - & - & - & - & - \\
\hline & 7 & 7 & 4 & 1 & 4 & 1 & 3 & 2 & 2 & 3 & 2 & 4 & 2 & 4 & 1 & 5 & - & - & - & - & - & - & - & - & - & - & - & - & - & - \\
\hline & 1 & 10 & 4 & 1 & 4 & 1 & 4 & 1 & 4 & 1 & 4 & 1 & 3 & 1 & 3 & 2 & 3 & 2 & 3 & 2 & 3 & 2 & - & - & - & - & - & - & - & - \\
\hline & 2 & 8 & 4 & 1 & 4 & 2 & 4 & 2 & 3 & 2 & 3 & 3 & 3 & 3 & 2 & 4 & 1 & 5 & - & - & - & - & - & - & - & - & - & - & - & - \\
\hline & 3 & 8 & 4 & 1 & 4 & 1 & 4 & 1 & 3 & 2 & 3 & 2 & 3 & 2 & 3 & 2 & 3 & 4 & - & - & - & - & - & - & - & - & - & - & - & - \\
\hline $\mathrm{B} 2 \mathrm{P} 2$ & 4 & 9 & 4 & 1 & 4 & 1 & 4 & 1 & 4 & 1 & 4 & 2 & 3 & 2 & 3 & 2 & 3 & 5 & 2 & 5 & - & - & - & - & - & - & - & - & - & - \\
\hline & 5 & 8 & 4 & 1 & 4 & 1 & 3 & 1 & 3 & 1 & 3 & 2 & 3 & 2 & 3 & 2 & 3 & 2 & - & - & - & - & - & - & - & - & - & - & - & - \\
\hline & 6 & 9 & 4 & 1 & 4 & 2 & 3 & 2 & 3 & 2 & 2 & 3 & 2 & 3 & 2 & 4 & 2 & 5 & 1 & 5 & - & - & - & - & - & - & - & - & - & - \\
\hline & 7 & 12 & 4 & 1 & 4 & 1 & 4 & 1 & 4 & 1 & 3 & 1 & 3 & 2 & 3 & 2 & 3 & 2 & 3 & 2 & 3 & 3 & 2 & 4 & - & - & - & - & - & - \\
\hline
\end{tabular}

Sumber : Hasil Pengamatan

(cc) BY-SA 
Tabel 2. Penanganan Pasca Panen Sayuran Terung Ungu (Solanum melongena) Perlakuan Suhu Ruang dan Suhu Rendah

\begin{tabular}{|c|c|c|c|c|c|c|c|c|c|c|c|c|c|c|c|c|c|c|c|c|c|c|c|c|c|c|c|c|c|c|}
\hline \multirow{3}{*}{ Bahan } & \multirow{3}{*}{ UL } & \multirow{3}{*}{$\begin{array}{l}\text { US } \\
\text { (hari) }\end{array}$} & \multicolumn{28}{|c|}{ Hari ke- } \\
\hline & & & \multicolumn{2}{|c|}{1} & \multicolumn{2}{|c|}{2} & \multicolumn{2}{|c|}{3} & \multicolumn{2}{|c|}{4} & \multicolumn{2}{|c|}{5} & \multicolumn{2}{|c|}{6} & \multicolumn{2}{|c|}{7} & \multicolumn{2}{|c|}{8} & \multicolumn{2}{|c|}{0} & \multicolumn{2}{|c|}{10} & \multicolumn{2}{|c|}{11} & \multicolumn{2}{|c|}{12} & \multicolumn{2}{|c|}{13} & \multicolumn{2}{|c|}{14} \\
\hline & & & $\mathrm{T}$ & W & $\mathrm{T}$ & W & $\mathrm{T}$ & W & $\mathrm{T}$ & W & $\mathrm{T}$ & W & $\mathrm{T}$ & W & $\mathrm{T}$ & W & $\mathrm{T}$ & W & $\mathrm{T}$ & W & $\mathrm{T}$ & W & $\mathrm{T}$ & W & $\mathrm{T}$ & W & $\mathrm{T}$ & W & $\mathrm{T}$ & W \\
\hline & 1 & 10 & 4 & 1 & 3 & 1 & 2 & 1 & 2 & 2 & 2 & 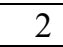 & 2 & 2 & 2 & 3 & 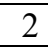 & 3 & 2 & 3 & 1 & 3 & - & - & - & - & - & - & - & - \\
\hline & 2 & 9 & 4 & 1 & 4 & 1 & 3 & 1 & 3 & 2 & 3 & 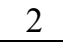 & 2 & 3 & 2 & 3 & 2 & 3 & 1 & 4 & 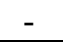 & - & - & - & - & - & - & - & - & - \\
\hline & 3 & 11 & 4 & 1 & 4 & 1 & 4 & 1 & 4 & 2 & 4 & 2 & 3 & 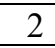 & 3 & 2 & 3 & 2 & 3 & 2 & 2 & 2 & 2 & 3 & - & - & - & - & - & - \\
\hline T1P1 & 4 & 10 & 4 & 1 & 4 & 2 & 4 & 2 & 4 & 2 & 4 & 2 & 3 & 2 & 3 & 2 & 3 & 2 & 3 & 2 & 2 & 3 & - & 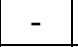 & - & - & - & 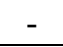 & - & \\
\hline & 5 & 10 & 4 & 1 & 3 & 1 & 3 & 1 & 3 & 1 & 3 & 2 & 3 & 2 & 3 & 2 & 3 & 3 & 3 & 2 & 2 & 2 & - & - & - & - & - & - & - & - \\
\hline & 6 & 11 & 4 & 1 & 3 & 1 & 3 & 2 & 3 & 2 & 2 & 2 & 2 & 3 & 2 & 3 & 2 & 4 & 2 & 4 & 20 & 4 & 1 & 4 & $\square$ & - & 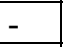 & - & - & - \\
\hline & 7 & 10 & 4 & 4 & 3 & 1 & 3 & 2 & 3 & 2 & 3 & 3 & 3 & 3 & 3 & 3 & & 4 & 2 & 4 & 1 & 4 & - & 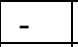 & - & - & - & - & - & - \\
\hline & 1 & 13 & 4 & 1 & 4 & 1 & & 1 & 3 & 2 & 3 & & 3 & & 3 & 2 & & 2 & 3 & 2 & 3 & & 2 & 2 & 2 & 2 & 1 & 3 & - & \\
\hline & 2 & 10 & 4 & 1 & 4 & 1 & 3 & 1 & 3 & 1 & 3 & 2 & 2 & 3 & 2 & 3 & 2 & 3 & 1 & 3 & 1 & 4 & - & - & - & - & - & - & - & - \\
\hline & 3 & 11 & 4 & 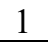 & 4 & 1 & 4 & 1 & 4 & 1 & 4 & 2 & 4 & 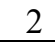 & 4 & 2 & 4 & 2 & 3 & 2 & 3 & 2 & 2 & 2 & - & - & - & - & - & - \\
\hline T1P2 & 4 & 11 & 4 & 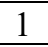 & 4 & 2 & 4 & 2 & $\begin{array}{lll}4 \\
\end{array}$ & 2 & 4 & 2 & 4 & 2 & 3 & 2 & 3 & 2 & 3 & 2 & 3 & 2 & 2 & 2 & - & - & - & - & - & - \\
\hline & 5 & 12 & 4 & 1 & 2 & 2 & 3 & 2 & 3 & 2 & 3 & 2 & 3 & 2 & 3 & 2 & 3 & 2 & 3 & 2 & 3 & 2 & 3 & 2 & 3 & 4 & - & - & - & - \\
\hline & 6 & 11 & 4 & 1 & 4 & 1 & 3 & 1 & 3 & 1 & 3 & 2 & 2 & 3 & 2 & 4 & 2 & 4 & 2 & 4 & 2 & 4 & 1 & 4 & - & - & - & - & - & - \\
\hline & 7 & & 4 & 1 & 4 & 1 & 4 & 1 & 3 & 2 & 3 & 2 & 3 & & 5 & 2 & 3 & 2 & 8 & 3 & 3 & & 2 & 3 & - & - & - & - & - & - \\
\hline & 1 & $>1$ & 4 & 1 & 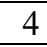 & 1 & & 1 & 4 & 4 & 4 & & 4 & & 4 & 2 & & 2 & & & & & 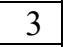 & 2 & 3 & 2 & 3 & 1 & 2 & 1 \\
\hline & 2 & 10 & 4 & 1 & 3 & 2 & 3 & 2 & 3 & 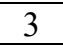 & 3 & 3 & 2 & 3 & 2 & 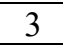 & 2 & 3 & 1 & 3 & 1 & 4 & - & - & 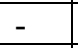 & - & - & - & - & - \\
\hline & 3 & 13 & 4 & 1 & 4 & 1 & 4 & 1 & 4 & 2 & 4 & 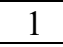 & 4 & 2 & 3 & 2 & 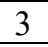 & 2 & 3 & 2 & 3 & z & 3 & 3 & 3 & 3 & 3 & 2 & - & - \\
\hline $\mathrm{T} 2 \mathrm{P} 1$ & 4 & 13 & 4 & 1 & 4 & 2 & & 2 & 4 & 2 & 4 & 2 & 4 & & 4 & 2 & & 2 & 4 & 2 & 4 & & 3 & 2 & 3 & 2 & 3 & 2 & - & - \\
\hline & 5 & 12 & 4 & 1 & 4 & 1 & 4 & 1 & 4 & 1 & 4 & 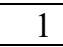 & 4 & & 2 & 1 & 3 & 1 & 3 & 1 & 3 & 1 & 3 & 1 & 3 & 2 & - & - & - & - \\
\hline & 6 & 9 & 4 & 1 & 4 & 1 & 3 & 1 & 3 & 1 & 3 & 1 & 3 & 2 & 3 & 2 & 2 & 3 & 2 & 4 & - & - & - & - & - & - & - & - & - & - \\
\hline & 7 & 1 & 4 & 1 & 4 & 1 & 4 & 1 & 4 & 2 & 4 & 2 & 4 & 2 & 4 & 2 & 4 & 2 & 4 & 2 & $J$ & 2 & 3 & 2 & 3 & 2 & 3 & 2 & - & - \\
\hline & 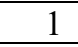 & $>1$ & 4 & 1 & 4 & 1 & & 1 & 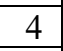 & 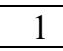 & 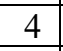 & & 4 & & - & - & & 4 & 4 & 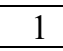 & 4 & & 4 & 1 & \begin{tabular}{|l|}
3 \\
\end{tabular} & 1 & 3 & \begin{tabular}{|l|}
1 \\
\end{tabular} & 3 & 1 \\
\hline & 2 & 10 & 4 & 1 & 4 & 1 & 4 & 1 & 3 & 1 & 3 & 2 & 5 & 2 & $J$ & 3 & 2 & 3 & 2 & 3 & 2 & 4 & - & - & - & - & - & - & - & - \\
\hline & 3 & $>1$ & 4 & 1 & 4 & 1 & 4 & 1 & 4 & 1 & 4 & 1 & 4 & 1 & 4 & 1 & 4 & 2 & 3 & 2 & 8 & 2 & 3 & 2 & 3 & 2 & 3 & 2 & 3 & 2 \\
\hline $\mathrm{T} 2 \mathrm{P} 2$ & 4 & $>1$ & 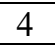 & 1 & 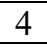 & 1 & 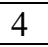 & 1 & 4 & 1 & 4 & 1 & 4 & & 4 & 1 & 4 & 1 & $T$ & 1 & $J$ & 1 & 3 & 1 & 3 & 1 & 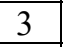 & 1 & 3 & 1 \\
\hline & 5 & 12 & 4 & 1 & 4 & 1 & 4 & 1 & 4 & 1 & 4 & 7 & 4 & & 3 & 4 & 3 & 4 & 3 & 4 & 3 & 4 & 3 & 1 & 3 & 2 & - & - & - & - \\
\hline & 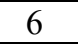 & 11 & 4 & 1 & 4 & 1 & 3 & 1 & 3 & 2 & 3 & 2 & 3 & 2 & 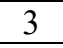 & $J$ & 3 & 5 & 2 & 3 & 2 & 3 & 2 & 4 & & 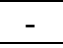 & 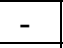 & - & - & - \\
\hline & 7 & 12 & 4 & 1 & 4 & 1 & 4 & 1 & 4 & 1 & 4 & 1 & 4 & 2 & 4 & 2 & 4 & 2 & 4 & 2 & 4 & 2 & 3 & 3 & 3 & 3 & - & - & - & - \\
\hline
\end{tabular}

Sumber : Hasil Pengamatan

(c) Br.SA 


\section{Strategi Sosialisasi Penanganan Pasca Panen Kepada Masyarakat}

Pada prinsipnya komoditas yang makin lama penyimpanannya maka cadangan energi akan semakin berkurang sehingga menyebabkan menurunnya kualitas sayuran seperti terjadinya pelunakan. Berdasarkan gambar 1 dan 2. perlakuan terbaik untuk mempertahankan umur simpan sayuran adalah penyimpanan suhu rendah dengan kemasan plastik. Hal ini sejalan dengan penelitian Paath et al. (2017) bahwa penyimpanan pada suhu rendah merupakan cara yang efektif untuk memperpanjang umur simpan bahan segar, karena dengan cara ini dapat mengurangi kegiatan respirasi, proses penuaan, dan pertumbuhan mikroorganisme. Pendinginan akan memperlambat atau mencegah terjadinya kerusakan tanpa menimbulkan gangguan pada proses pematangan dan memperlambat pelayuan.

Pengemasan dengan plastik dapat menjaga dan melindungi produk dari paparan lingkungan luar. Berdasarkan penelitian Mareta et al. (2011) bahwa adanya wadah atau pembungkus dapat membantu mencegah atau mengurangi kerusakan, melindungi produk yang ada di dalamnya, melindungi dari bahaya pencemaran serta gangguan fisik (gesekan, benturan, getaran). Hal ini dimaksudkan untuk menghindari adanya respirasi dan transpirasi yang berlebih pada sayuran. Sejalan dengan Paath et al. (2017) bahwa aktivitas respirasi dan transpirasi yang tinggi pada penyimpanan suhu ruangan menyebabkan kehilangan air yang cukup banyak sehingga ukuran sel dan tekanan isi sel terhadap dinding sel berkurang yang akhirnya mengakibatkan tekstur menjadi lunak. Penurunan kekerasan selama penyimpanan terjadi karena perombakan komponen penyusun dinding sel sehingga buah semakin melunak.

Oleh karena itu sosialisasi penanganan pascapanen sayuran sangat diperlukan untuk meningkatkan pengetahuan masyarakat mengenai tata cara menyimpan sayuran agar umur simpan lebih panjang. Berdasarkan penelitian Hamidah (2015) bahwa buah dan sayur merupakan tumbuhan yang mudah rusak, kerusakan ini relatif tinggi terutama di negara berkembang yaitu antara 30\%-50\%. Kerusakan ini terjadi karena pemahaman tentang penanganan pasca panen bagi kebanyakan orang belum memadai disamping dukungan teknologi perawatan bahan pangan yang belum memungkinkan.

Sosialisasi pasca panen ini sangat penting dikarenakan adanya pandemi COVID-19 merupakan fenomena luar biasa yang terjadi di bumi pada abad ke 21 . Fenomena ini bukan hanya menelan korban, tetapi juga berdampak pada segala aspek kehidupan manusia seperti kesehatan, ekonomi, sosial, pendidikan, politik, dan masih banyak lagi (Aslamiyah 2021). Salah aspek yang paling terdampak adalah aspek kesehatan. Daya tahan tubuh masyarakat ditengah pandemi COVID-19 selalu menjadi perhatian masyarakat. Oleh karena itu, dalam rangka meningkatkan daya tahan tubuh masyarakat semakin sadar untuk mengonsumsi makanan sehat seperti sayuran.

Strategi sosialisasi penanganan pascapanen sayuran dengan menggunakan pemanfaatan teknologi internet. Tentunya strategi lanjutan yang lebih spesifik perlu ditetapkan secara tepat. Salah satu strategi yang dapat diterapkan yakni melalui sosial media. Peran media dalam sosialisasi pasca panen sangat menunjang di era digital saat ini. Di era digital tentu strategi tersebut sangat efektif dan tidak asing untuk mengenalkan pascapanen secara masif.

Strategi menggunakan media internet sangat efektif untuk mengenalkan penanganan pasca panen sayuran melalui edukasi seperti di Social Media Ads seperti facebook, instagram, twitter, dan 
sebagainya dengan harapan edukasi pengananan pascapanen lekas viral.

Penggunaan website juga dapat dilakukan. Bekerjasama dengan Kementrian Pertanian meyakinkan masyarakat dan memudahkan untuk mengetahui prinsip pasca panen. Website ini akan menyajikan informasi/artikel pendukung untuk menarik masyarakat.

Strategi lain yakni bekerja sama dengan tokoh masyarakat seperti ketua RT untuk konsinyasi dengan maksud mengedukasi warganya mengenai pentingnya pengelolaan pasca panen. Pemberdayaan dilakukan oleh kelompok wanita yang termasuk dalam PKK (Pemberdayaan Kesejahteraan Keluarga) yang umumnya sebagai pelaku untuk mengembangkan kemandirian pangan dengan adanya pengetahuan mengenai pasca panen yang benar, maka pangan utamanya sayuran dapat memiliki umur simpan yang panjang. Dari sinilah upaya kerjasama untuk saling mengedukasi pasca panen terwujud ditengah pandemic COVID-19.

\section{KESIMPULAN}

Perlakuan yang terbaik pada penyimpanan sayuran terung dan bayam yaitu dengan perlakuan kemasan di suhu rendah. Pengemasan dengan menggunakan plastik merupakan upaya penanganan pasca panen untuk menekan laju respirasi. Strategi sosialisasi penanganan pascapanen ditengah pandemic COVID-19 dapat memanfaatkan teknologi internet serta bekerjasama dengan berbagai pihak untuk melakukan edukasi pasca panen kepada masyarakat luas.

\section{DAFTAR PUSTAKA}

Abriana, A., \& Laga, S. (2019). Penanganan Pasca Panen Sayur Brokoli di Kabupaten Enrekang. $J$ Ecosystem, 19(1), 45-50.
Asgar, A. (2017). Pengaruh Suhu Penyimpanan dan Jumlah Perforasi Kemasan terhadap Karakteristik Fisik dan Kimia Brokoli (Brassica oleracea var. Royal G) Fresh-cut. J. Hort., 27(1), 127-136.

Aslamiyah, S. (2021). Dampak Covid-19 terhadap Perubahan Psikologis, Sosial dan Ekonomi Pasien Covid-19 di Kelurahan Dendang, Langkat, Sumatera Utara. $J$ Riset dan Pengabdian Masyarakat, 1(2), 56-69.

BPS. (2017). Konsumsi Buah dan Sayur Susenas Maret 2016, http://gizi.depkes.go.id/wpcontent/upl oads/2017/01/Paparan-BPS-

Konsumsi-BuahDan-Sayur.pdf.

Diakses pada 11 Juni 2021.

Yuarini, D.A., Satriawan, I.K., \& Suardi, I.D. (2015). Strategi Peningkatan Kualitas Produk Sayuran Segar Organik pada CV. Golden Leaf Farm Bali. J Manajemen Agribisnis 3(2), 93 $-109$.

Mareta, D.T., \& Awami, S. N. 2011. Pengemasan Produk Sayuran dengan Bahan Kemas Plastik Pada Penyimpanan Suhu Ruang dan Suhu Dingin. J.Mediagro. Vol 7 (1): 27-40.

Hakiki, D.N. (2016). Perubahan Kualitas Pasca Panen Bayam Organik selama Penyimpanan setelah Perlakuan Heat Shock dan Hydrocooling. J Keteknikan Pertanian, 4(1), 53-58.

Hamidah, S. 2015. Sayuran dan Buah serta Manfaatnya bagi Kesehatan. Jurnal Teknik Pascapanen, 1(2), 11.

Herdiani E. 2015. Pascapanen sayuran. Balai Besar Pelatihan Pertanian

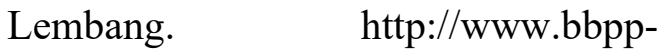
lembang.info/index.php/arsip/artikel/a rtikelpertanian/941-pasca-panensayuran. Diunduh 8 Juni 2021

Juhaeti, T., \& Peni, L,. (2016). Pertumbuhan, Produksi dan Potensi 
Gizi Terung Asal Enggano pada Berbagai Kombinasi Perlakuan Pemupukan. J Ilmu-ilmu hayati, 15(3), 303-313.

Paath, V.V., Frans, W., \& Ireine, L. (2017). Kajian Pengemasan terhadap Mutu Terung Ungu (Solanum melongena L) selama Penyimpanan. $J$ Coconut, (7), $1-8$.

Roiyana, M., Izzati, M., \& Prishastanti. (2012). Potensi dan Efisiensi Senyawa Hidrokoloid Nabati sebagai Bahan Penunda Pematangan Buah. Jurnal Anatomi dan Fisiologi Tumbuhan, 10(1), 40-44.
Waryat, \& Handayani, Y. (2020). Implementasi Jenis Kemasan untuk Memperpanjang Umur Simpan Sayuran Pakcoy. J Ilmiah Respati, 11(1), 33-45.

Yudhistira, B., Sari, T.R., \& Affandi, D.R. (2019). Karakteristik Fisik, Kimia dan Organoleptik Cookies Bayam Hijau (Amaranthus tricolor) dengan Penambahan Tomat (Solanum lycopersicum) sebagai Upaya Pemenuhan Defisiensi Zat Besi pada Anak-Anak. J Warta Industri Hasil Pertanian, 36(2), 83-95. 